Indonesian Journal of EFL and Linguistics

Vol. 3 No. 1, 2018

eISSN: 2503-4197, pISSN: 2527-5070

www. indonesian-efl-journal.org

\title{
Learner Autonomy: Gender-Based Perception among EFL Indonesian Students
}

\author{
Moch. Said Mardjuki \\ Universitas Pendidikan Indonesia \\ e-mail: saidmardjuki@gmail.com
}

\begin{abstract}
:
Learner autonomy is believed to be the contributing factor toward the students' successful learning process. However, its implementation in Indonesia still faces some challenges regarding students' readiness and competencies in realizing such concept. Thus, this study is aimed to investigate gender-based perceptions and attitudes among EFL Indonesian students on learner autonomy. Qualitative design in which four out of twenty respondents were selected purposively under the rationale that they demonstrated positive evidences reflected to the preliminary questionnaire results. Using semi-structured interview, the findings indicated no gender-based discrepancy in terms of learning experiences and challenges. Although individual tasks were preferred by both groups, problem-solving strategies differ in which females employed internal strategies (rescheduling and selfcommitment), while males employed external strategies (learning sources and collaborative works). In conclusion, each of the autonomous learners has personal preference to deal with the encountered challenges. Further researches, thus, need to investigate the actual transparencies of their learning behavior through observation.
\end{abstract}

Keywords: learner autonomy, learning process, gender, perceptions, attitudes 


\section{INTRODUCTION}

Learner autonomy becomes major concern in English as second or foreign language teaching. It is believed that the success of learners' learning depends on the way they learn the language independently with appropriate learning strategies. Thus, it is impacted to the teaching and learning process in which the learner becomes the center of attention in language learning in education of some places including in Indonesia. However, in reality, the implementation of learner autonomy as it is mandated by the government in the latest curriculum, 2013 Curriculum faces some challenges particularly the readiness of the students to be the central part of the teaching and learning process and teachers' competencies in employing learner autonomy through various teaching activities.

Thus, this study is aimed to investigate gender-based perception among EFL Indonesian students on learner autonomy. Learner autonomy is a modal for the learners who are pursuing higher education degree (Balcikanli, 2008). Such modal is translated into six abilities to have including: "setting learning goals; identifying and developing learning strategies to achieve such goals; developing study plans; reflecting on learning (which includes identifying problem areas and means of addressing these problems); identifying and selecting relevant resources and support; assessing one's own progress (which includes defining criteria for evaluating performance and learning) (Holec, 1981). Based on the circumstances listed, this present study aims to investigate the students' perception of learner autonomy and the way they become learner autonomy which is based on gender.

Several researches related to learner autonomous have been established. Chan (2010) in her research found that the teachers' roles have influenced the process of gaining learner autonomy by the students. Another study conducted by Lengkanawati (2017) on such concept revealed that the teachers' roles and guidance are needed in fostering learner autonomy in classroom context. Moreover, Yuliani and Lengkanawati (2017) in their research acknowledged that by employing projectbased activities are able to promote learner autonomy. Thus, researches related to gender-based learner autonomy have also conducted by Varol and Yilmaz (2010) and Abdel Razaq (2014). Varol and Yilmaz (2010) in their research found that there were no significance differences between male and female related their learning activities as autonomous learners. On the other hand, Abdel Razaq (2014) in his research revealed that there was discrepancy between male and female students related to their learning activities as autonomous learner.

Despite profoundly investigated, the aforementioned studies still demonstrate certain gaps. There is insufficient evidence regarding gender-based learner autonomy in Indonesian context. Besides, challenges encountered along with the problems solving strategy employed in the students' learning process are also in absence. In the effort to address such gaps, the present study was aimed at seeking students' perceptions and attitudes toward learner autonomy. This encompasses learning experiences, learning strategies, learning challenges, and problem solving strategies. 


\section{LITERATURE REVIEW}

This chapter unpacks some important points regarding learner autonomy including: definition of learner autonomy; characteristics of autonomous learners, learning process of autonomous learner, and learning challenges as autonomous learner.

\subsection{Learner Autonomy}

The commonly term of learner autonomy firstly introduced by Henri Holec in 1981 . He defines learner autonomy as 'the ability to take charge of one's own learning' (p.3). Since it was introduced by Holec in 1981. There are a number of definitions related to learner autonomy depending on the context of the writer. Benson (2001) conceptualizes learner autonomy as someone's competence in learning management. In line with Benson, Little (1996) describes learner autonomy as the capability and disposition of the learner in decision making process independently. Macaro (2008) emphasizes on individual learning outcomes under such decision making process as stated in the following statements:

Having a choice in their own language learning means the language learner or user taking control not only of the language being learnt, but also of the goal and purpose of that learning... Autonomy resides in being able to say what you want to say rather than producing the language of others... (pp. 59-60)

Both characteristics lead to the act of responsibility toward their own lifelong learning empowerment (Egel, 2009). Moreover, Dickinson (1987) considers the concept of learner autonomy as the students' flexibility in managing outsideclassroom learning.

In EFL context, it was believed that learners' decision making about how they learned and what activities they did, and involving them to decide what and how to learn could promote autonomy among learners (Lengkanawati, 2017). Another indicator is learner autonomy concern on students' sense of responsibility for ensuring their progress during English lessons (Abdel Razeq, 2014). In addition, self-instruction realized by activating problem solving skill in which they are able to accomplish the work without the teachers' control is included (Dickinson, as cited in Kumaravadivelu, 2003).

\subsection{Characteristics of Autonomous Learner}

With respect to the conception of learner autonomy, some experts furtherly propose that the students can be categorized as being autonomous under at least seven characteristics. First, the students are able to "develop a capacity for critical thinking, decision making, and independent action." Second, they are capable of discovering "their learning potential, in addition to merely gathering knowledge about the learning process." Third, they are able to "take responsibility for learning and for using appropriate strategies to achieve their general and specific objectives. "Fourth, they can "face heavy psychological demands that require learners to confront their weaknesses and failures. "Fifth, they can maintain "self-control and self-discipline, which lead to self-esteem and self-confidence." Sixth they tend to give up total dependence on the teacher and the educational system." Seventh, they 
can "understand that autonomy is a complex process of interacting with one's self, the teacher, the task, and the educational environment." (Kumaravadivelu, 2003).

Furthermore, there are some supporting characteristics of autonomous learner (Kumaravadivelu, 2003). First, autonomous learner depends on collaborative work. Second, the dynamic circumstances of autonomy are influenced by personality and motivation toward the administered learning process. Third, autonomy is contextbound in which the learners may encounter obstacles in their learning process within which they possibly ask for the teachers' guidance.

\subsection{Learning Process of Autonomous Learner}

Related to learning process for shaping autonomous learners, several activities may be implemented in the classroom setting by the teachers. First thing first, they should prepare the students' role in classroom involvement through providing clear objectives so that they will know what should they do and what they can do in the next meeting. Another point concerns on out-of-class experience allowing the students to integrate the content knowledge with authentic prior knowledge. It leads to the use of authentic materials and real language because it fosters personal relevance. Besides, they should be encouraged to seek for information through independent inquiry triggering personal interest. This is not limited to information finding, but also related to designing the tasks with students' involvement. Thus, it promotes meaningful student-student interaction regarding the learning content. Peer teaching can be a means of enhancing such interaction as well. In terms of assessment, the teachers need to be tolerance in understanding divergent students' outcomes reflected particularly from individual production. One of the ways in its realization is self and peer assessment for the sake of their own benefits. The last but not least is self-reflection which is done by them through concurrent interaction (through talking and writing) between the teachers and the students regarding the completed activities and the following ones (Benson, 2016).

From the learner side, Chan (2010) mentions six expectations to be noted by the students. They are: "setting learning goals; identifying and developing learning strategies to achieve such goals; developing study plans; reflecting on learning (which includes identifying problem areas and means of addressing these problems); identifying and selecting relevant resources and support; assessing one's own progress (which includes defining criteria for evaluating performance and learning)."

\subsection{Learning Challenges as Autonomous Learner}

Learning challenges as autonomous learners may occur as the influences of the perception that learner autonomy is driven from the west which identical with liberated and individualism of democratic (Benson, 1997, Pennycook, 1997 \& Lengkanawati, 2017). Several factors may lead as the challenges in implementing learner autonomy. Those factors include the teachers' perspectives and beliefs related to learner autonomy, teachers' lack of competencies, and learners' lack of experience as autonomous learner. Firstly, teachers' perspective and beliefs related to learner autonomy become one major factor in which can significance impacted to 
the success of the implementation of it. The skepticism of implementing happens when the teachers think that it is contra cultural norms and against teaching paradigm (Ranosa-Madrunio, Tarrayo, Tupas \& Valdez, 2016). Since they consider that the main duty of teacher is teaching in which the teacher is as the main part of teaching and learning process. Thus, since it is affiliated with the west. They consider that the teaching and learning process neglect the roles of teacher who are not only teaching but also to portray their national character building.

Secondly, teachers' lack in employing various teaching activities into the classroom would be the other consideration related to the learning challenges as autonomous learner. Abdel Razeq (2014) acknowledged that the students may achieve their learning objectives if there is supporting motivation, inspiration, as well as improvement by the well-trained teachers. Considering the results of his study on students' learning environment under untrained teachers, it can be concluded that the higher student motivations they have, the higher possibility they can achieve their learning objectives. Indeed, it should be facilitated by well-trained teachers who have equiped with the holistic development in education.

Thirdly, the learners' lack of experience about learner autonomy also becomes the major obstacle in applying learner autonomy. It is because they feel that the main task of the teacher is teaching in which they prefer to have guidance in doing their learning activities. It is influential to their outcome in which their learning success is based on the teachers' performance. It is also supported by Lewis and Reinders (2008) in their research found that the shift of teacher-centered learning to studentcentered learning is something not easy to do. There is a major challenge in encouraging learner autonomy. The major challenge "lies in teacher-centered students in which they might be accustomed to the teachers having and giving readily the answers."

\subsection{Previous Studies}

There are some researches that have established learner autonomy. Among them are the works of Chan (2010), Lengkanawati (2017), Yuliani and Lengkanawati (2017), Varol and Yilmaz (2010), and Abdel Razeq (2014).

A research conducted by Chan (2010) at Hong Kong Polytechnic University relating to the phenomenon of learning autonomy among university students. The study reveals that the students have already gained learner autonomy from the role of the teachers. They are able to manage their learning goals in terms of learning preferences, approaches, and as well as their decision in using various learning strategies. Thus, they have already gained clear learning goals, learning strategies, and preferences of learning in which it would lead them to achieve it. One of the characteristics is that they are willing to be more actively participated in the teaching and learning process in the classroom. Teachers should encourage the students' awareness on identifying the levels of autonomy because they might not have adequate prior knowledge about the concept of learner autonomy.

Lengkanawati (2017) in her research on learner autonomy in the Indonesian EFL settings revealed that learners become integrated part of autonomy in which they 
have to be taught related to autonomy and the role of teacher is needed in the teaching and learning process. Thus, learners' choices, decisions to what kind of activities and the way they learn will encourage learner autonomy among them. Moreover, the majority of the participants prefer to apply the principles of learner autonomy into their classroom, however, they realize that there are some principles of learner autonomy which may inappropriate to apply in some teaching-learning contexts. Thus, she suggests that the inculcation of learner autonomy for the teachers needs to be mandated in teacher education programs.

As regards to the implementation of various activities which can promote learner autonomy, Yuliani and Lengkanawati (2017) on their study at the ninth grade students of one public junior high school in Bandung revealed that by employing project-based learning in EFL classroom context would able to promote learner autonomy. The study found six important findings. They include: (1) learner autonomy differs across learners in terms of task completion strategy; (2) learner autonomy conforms to learning achievement; (3) the process of fostering learner autonomy exhibits dynamic patterns; (4) learner autonomy is not fully absolute; (5) learners demonstrate higher degree of learner autonomy within the implementation process of project-based activity; (6) learner autonomy also deals with obstacles.

Regarding researches on gender and autonomous learners. A research conducted by Varol and Yilmaz (2010) on investigating the similarities and differences learning activities as autonomous learner between male and female students at a state primary school revealed that there was no discrepancy between male and female students regarding their learning activities as autonomous learners. However, female students demonstrated more frequency in terms of learning activities involvement. On the other hand, Abdel Razeq (2014) in his research found that there was discrepancy difference on autonomous learner activities toward gender. The study revealed that female students were more active rather than male students in terms of their interest in learning English. One of the reasons behind the discrepancy is the females tend to prefer production-based activities like speaking.

\section{RESEARCH METHODOLOGY}

This study employed qualitative research design aiming at exploring and understanding the issues that have impacts on behavior (Hamied, 2017). Nevertheless, the objectives of this study are not supposed to generalize learner autonomy between male and female EFL learners. In other words, the result of this study would not portray a whole value, or related conditions in other environments might show new different outlooks (Sugiyono, 2013). This design was chosen since this study tried to investigate how learner autonomy of Indonesia English foreign learner differs across gender in comprehensive ways which were still easily understood.

On data collection procedures conducted in the study, it comprises respondents involved in the study, instrumentation and materials, and procedures taken in collecting the data. The respondents of the present study were four EFL postgraduate students at one state university in Bandung: two males and two females. They were 
selected purposively to participate in the study since they have adequate information related to learner experience as autonomous learner (Creswell, 2012). Furthermore, they have been studying for about three semesters. Since then, they might have been applying some strategies in learning English as autonomous learner of foreign language.

Research instrument of the present study was semi-structured interview. This instrument was chosen by the researcher in order to gather deep information regarding the respondents learning experiences as autonomous learners as well as their learning strategies. The semi-structured interview was adopted from Chan (2010) and it is enclosed in the appendices. This instrument is aimed to address the following research question, "How does learner experience between Indonesian EFL male and female autonomous students differ?"

Preliminary questionnaire was administered through Google Form to twenty EFL postgraduate students at one state university in Bandung. It was administered to ten males and ten females of third semester EFL postgraduate students. The results showed that most of the respondents tend to be autonomous as with the percentage of the three sequences (teachers' role, learners' role, and learning preferences). Later, interview was administered to the four EFL postgraduate students whom two of them are females, while the other two are males. The consideration of choosing the respondent is based on the equality of gender representativeness.

Before collecting the data, the interview protocol was formulated based on Chan (2010) on October $25^{\text {th }}, 2017$. The semi-structured interview mainly consists of five questions. The questions are related to the learning experiences, learning strategies, learning challenges, and the way to solve the challenges. After the interview was being accomplished, the researcher selected the respondents purposively on October $30^{\text {th }}, 2017$. Later, on November $1^{\text {st }}, 2017$, the interviews were conducted. The last step was transcribing the interview on November $1^{\text {st }}$ to $3^{\text {rd }}, 2017$. The transcription was returned to the interviewees on November $4^{\text {th }}, 2017$. It aims to check the suitability with the data that they already gave.

The data obtained were analyzed in qualitative way. It assigned the data analysis technique proposed by Miles and Huberman (1994) who sequence the analysis through three steps: data reduction, data display, and conclusion drawing/verification. The data gained from interview were classified into four major themes: learning experiences, learning strategies, learning challenges, and the way to solve the challenges based on gender. Thus, after breaking down the themes, data were then displayed in the form of description based on research question based on gender. After displaying the data for each research question, generalization of data interpretation was made.

\section{FINDINGS}

In this section, the findings of the study will be elaborated. Moreover, the discussion of the findings will be based on the research question, "How does learner experience between Indonesian EFL male and female autonomous students differ?" 


\subsection{Learning Experiences among Autonomous Learners}

Learning experiences in the present study deals with the participants' learning experience in gaining knowledge as autonomous learner. It includes their attitudes towards learner autonomy. The respondents believe that autonomous learner are influenced by the classroom situation in which there are interconnected between teacher and students in terms of teacher's role. The majority of the respondents agreed that the teacher's role in the classroom is able to promote learner autonomy. The teacher's role would be in the forms of teacher's guidance, teacher's assignment, and teacher's experience. In terms of teacher's guidance, the respondents believe that by having guidance during teaching and learning process are able to promote them as learner autonomy. Some argue that:

You should be guided by the lecturer. I prefer the lecturer who is giving not only guideline but also guidance. I mean, guideline is more printed or written but guidance is more narrative not only giving materials and then okay you go on with your own critical thinking. (Irvin)

Teacher's guidance is essential or important I think. Because not all the students can manage themselves. (Robert)

It is influenced by the teachers because you have to follow the teacher's guidelines. (Lucy)

Some others said that there should be specific guidance during the teaching and learning process.

I need the teacher's guidance in the beginning to state what is actually the teacher wants or the teacher expects from my work or my learning (Emma).

I think the teacher's guidance is important in the middle of learning process (Robert).

I think that teacher's guidance is important. I think that being autonomous does not means that teacher does not have role. Teachers have role in guiding and giving feedback to the students. (Lucy)

However, Irvin describes that there is a consideration related to teacher's guidance. He states that when the students are expected to have collaborative learning through presentation in groups. There is no clear guidance before that then just give the topic. "Because we have objectives." Thus, there should have clear step-stones in guidance the students. Therefore, they acknowledged that the lectures usually display their syllabus in the first meeting.

... the lecturers always showed the syllabus regarding the objectives, the activities, and the assessments. (Robert)

There is a negotiation between the teacher and the students related to the topics, the themes of the tasks that the students want to choose. (Lucy) 
In contrary, one of the respondents confirmed negative attitudes to teacher's guidance.

Mostly it is not helpful. I do not know; I think it is not the lecturers but it is the tasks that trigger me to be more autonomous. (Irvin)

Related to the teacher's assignment, the majority of the respondents acknowledged that it is beneficial for them as autonomous learner in which they can gain their knowledge and share the knowledge as well in the form of writing tasks. One of them argued that the stance is still indecisive. Another respondent asserted an affirmation to teacher's assignment. Respectively, here is the following statement:

I hate assignments but without assignments I cannot learn. (Emma)

... how the teachers treat the students in the classroom whether the teachers give such kinds of assignments or tasks to the students to do it by individual or by group. (Robert)

Moreover, the respondents agreed that in conducting tasks either by individual or by group would trigger them as autonomous learner. Most of them work collaboratively when it is in the form of group presentation while individually for paper writing. It is clearly seen in the following:

I prefer individual tasks. It challenges me not only to be more autonomous but to increase my proficiency especially my English proficiency. Especially, writing skills. (Irvin)

When the teachers want to see the independent of the learners it can be seen from the individual tasks and when the teachers want to see the collaborative learning process then the teacher give group assignment. (Lucy)

Furthermore, teachers' feedback also plays as important part to promote learner autonomy since the students will be motivated in learning the language. As confirmed by Lucy, she agreed that the explanation and the instruction from the teachers give important points and the feedback is also important. She will know that she has worked as required or stated in the syllabus. However, no male respondents confirmed the same view as Lucy's.

... the explanation and the instruction from the teachers give important points and the feedback is also important because by receiving feedback the students know if they have done the tasks in correct way or not. (Lucy)

The last but not least regarding student's learning experience as autonomous learner, the teachers' previous learning experiences have also influenced to one of the respondents. Robert stated that he learns how to be an autonomous learner from his previous lecturers. Particularly when they were doing their thesis or dissertation as well when they were studying abroad. However, no female respondents confirmed the same view as Robert's.

Mostly I got it from their [teachers] learning experiences when they are doing their thesis or dissertation or when they are studying abroad. (Robert) 
Thus, the respondents acknowledged that extrinsic motivation influences them as autonomous learner. Some argue:

Because I think, in my perspective those skills are really helpful when someone wants to be academician because the consensus is that. The consensus is the academic writing is compulsory for everyone wanting to get better job especially when he or she wants to be academician. (Irvin)

I will be motivated to get the rewards. (Emma)

Those responses represent their understanding about learner autonomy. The respondents define learner autonomy as how the learners manage themselves to be independent learner. However, learner autonomy itself is not something that really independent, there should be teachers' role in guiding them to achieve their learning objectives and promote them as autonomous learners.

The same stance is demonstrated by Irvin that learning autonomy does not address to learning strategy in designing own learning. He conceptualized it as the involvement of teachers' acknowledgement on the students' proficiency.

\subsection{Learning Strategies among Autonomous Learners}

Relating to the learning strategies they employ as autonomous learner, the respondents were asked several questions leading them to explain their learning experience as autonomous learner. The respondents were asked regarding their learning management. The majority of the respondents acknowledged the same strategies:

... in the beginning of the semester, I directly make the blue print or planning. ...well-prepared write after the syllabus have been introduced. (Irvin)

I manage my learning firstly is by scheduling. The second one is by prioritizing, because we are assign so many assignments. So, I have to sort which one is the most urgent. (Robert)

I usually write down particular schedule of what have to do list I write my to-do list on the schedule board or on my diary, or my notes of what have to do today and what I have to do tomorrow. (Lucy)

.... I identify the subject. Then, I formulate the objectives... I set the time line when the assignment will be due ... I formulate my own expectations despite the teacher gives some expectations I also formulate my own expectations. (Emma)

All the respondents have the same perception related to learning resources, task preferences, and learning strategy. Related to learning sources, interestingly, the respondents have the same perceptions dealing with how they gain the knowledge despite of the teacher's role in the classroom.

I am accustomed to searching for more information especially in the internet or other sources. I usually look for more new information from internet. The rest of 
it, you use your own preferences to achieve the goals of the course for example. (Irvin)

...internet. There are abundant materials in internet that we can utilize to improve our learning and books. The books can be from the library or internet. (Lucy)

... learning sources from the internet. ... I usually read some journals. I ask someone who has the book. ... library or digital library. (Emma)

Thus, regarding task preferences, the respondents mostly agreed that individual tasks particularly in the form of writing is appropriate to conduct in individual. Whereas, in collaborative, it deals with group presentation. It is because both types of conducting assignment have its own strengths and weaknesses. Some argue:

I really like what the teacher is giving some individual tasks. I do not know but I am not a kind of person who is willing to be in a groups. In pairs yes but in groups no. In my perspective, if it is writing there are many perspectives. So, the writing can be questionable because there are many perspectives influencing the writing. It is different when you are presenting something in groups. Because you present it not write it. It is because we have clear roles what materials should be presented for each member. But, writing, it is only one work and many adds. I really like individual tasks. (Irvin)

... learning by myself is more effective than learning in a group with people who do not have the same focus. (Lucy)

... it depends on the learning subject or learning material. ... I prefer to work individually for the lesson that less the deep thinking. But if I have to work collaboratively I think it is for the type of lesson which needs the discussion. (Emma)

Moreover, the respondents have different motifs related to the individual learning. Male respondent focusses on feeling fear of questionable writing results under some students' perspective. On the other side, female respondents concern more on goal alignment among the group members (Lucy) and the level of task difficulty in which less deep thinking work is preferred to be individual activity.

In addition to task preferences, the respondents had the same views related to types of learning activities in promoting them as autonomous learner. They believe that by employing various learning activities such as, project-based, mini research, group presentation, and problem-based learning would engage the students to become autonomous learner. It is clearly seen on the following statement:

... project based paper, group presentation, individual paper, or mini research. It is really helpful. (Irvin)

I think project, task based learning will encourage students to do independent learning. (Lucy) 
Furthermore, the respondents described that there are some advantages from both sides either by employing those learning activities in group or by individual. Some argue:

I still prefer sharing to gain more knowledge. (Irvin)

... when your strategies do not work you have to think or to find others strategies to solve the problems by yourself or joining into group discussion. (Robert)

... group discussions. It is a good strategy for learners to find out other ideas from others learners. So, we can improve our understanding of certain topics. (Lucy)

Moreover, some of the respondents stated that they are not a date-liner and able to make well preparation as well in assessing the assignment. It can be clearly seen in the following:

I am not a date-liner. Although I am the last presenter. I directly look for relevant articles with the topics that I want to research. I am the person if I can assess myself, I am the person what is that can be said high curiosity. (Irvin)

I usually write some notes. I have to write the outlines of the assignment. (Lucy)

Regarding to the preferences of teaching and learning places, the majority of the respondents believe that the place for learning could be inside and outside the classroom. Since it is supported by technology, particularly information technology.

As $21^{\text {st }}$ century learners, we are encouraged to study by ourselves and maybe the teacher is not only the main source in the learning process. Thus, the students are able to use technology which provides lot of learning materials. (Lucy)

It is like chit-chat or simple sharing informal way in or out classroom. I usually prefer book because I cannot say that I have difficulty in reading eBooks. I prefer reading printed books because it is easier to me to move from one page to another page. (Irvin)

On the other hand, Robert acknowledged that he prefers learning in the classroom since he will become more focus than learning outside the classroom.

... learning inside the classroom. When we learn outside the classroom, we tend to be more enjoying our time alone. So, I do not focus [to my learning objectives]. (Robert)

In addition, related to learning preferences, one of the respondents described himself as independent learner who can gain his learning by himself in which less guidance from the teacher.

I can say that I am not dependent on the lecturers. So, whether the lecturer is giving clear information about the materials or not. I still learn it by myself outside the classroom. (Irvin) 
Thus, to sustain their ability regarding as learner autonomy, the respondents spend their specific time for reading. it could be in the forms of extensive and intensive reading. Regarding the intensive reading, it is usually based on the suggested books as it is stated on the syllabus, according to Irvin and Emma.

\subsection{Learning Challenges among Autonomous Learners}

The implementation of learner autonomy leads several challenges influenced by the students' behavioral habit and their situational learning process as autonomous learners. The respondents found that behavioral habit as the major obstacles for them as autonomous learner. Those challenges are clearly seen in the following:

When I get stuck with understanding some difficult terms and then when I am trying to get some clear information from other classmates and the answers are not clear enough and still questionable. It is really disaster. (Irvin)

The most challenging one is the laziness. Sometimes there is a kind of contradictory between me and also the fact or the reality in the real world. I did make a kind of schedules. Weekly, monthly schedule, and even yearly schedule but I did not commit to myself. That is the problem. Thus, when we learn outside the classroom, we tend to be more enjoying our time alone. So, I do not focus [to my learning objectives]. (Robert)

Actually for this day I cannot manage my time very well and also laziness or I cannot commit myself with the schedule I have written. Sometimes I can do what I have written on the schedule but mostly I do not do what I have written in the schedule. (Lucy)

The challenge is my mood swing. When I feel I like I am not in the mood to learn. I might not read at all. I might not learn at all even though I have already set some schedules. Thus, the dateline of task determinacy. (Emma)

The challenges from the respondents are basically in terms of the commitment from themselves to achieve what they have design as their learning objectives. Indeed, the inconsistency in their objectives will impact to their academic result.

\subsection{Strategy in Encounter Learning Challenges among Autonomous Learner}

Regarding to solve the challenges that the respondents met during their learning process as autonomous learner. They usually conduct several strategies. Those strategies are clearly seen in the following:

I keep looking for more information on google. So, I am really dependent on google, I am really dependent on articles. Especially on main resources because books are too much information in it. I can say that my attention span in reading is little. In reading books and to find out the definition, the clear information about some terms, some difficult terms is also difficult for me. So, I prefer articles. Because articles, the literature review for example have been structurally presented. Not too broad not too specific but its proportion is ideal. So, when I get stuck with some difficult terms in understanding the materials. I have to look for some related articles that related to the materials. (Irvin) 
I solve the problems [in learning] by taking part in the group discussion. When we are learning together then that kind of laziness can be avoided. (Robert)

I try my best to commit with the schedule. I rewrite the schedule and I manage the time remaining with the tasks to be done. I always reread my assignment or proofread and find out the mistakes. I usually evaluate the tasks by myself by rereading. (Lucy)

I am trying to commit to the reading hour. (Emma)

The respondents usually conduct informal discussion related to solve their challenges in learning as autonomous learner and trying to commit with their objective that they have design in the beginning of the semester. The majority believe that by having reflection to several obstacles that they met during their learning. They would able to avoid unexpected results at their academic result.

\section{DISCUSSION}

This study attempts to seek the EFL learners' perception and attitude on autonomous learner based on gender. Several findings were found. Regarding learning experiences as autonomous learners. Most of the respondents agree that teachers' role is contributed to their development as autonomous learner. It is line with what Chan (2010) found. She found that the teachers' role affected to the way the students become autonomous learners. The respondents pin points that teachers' guidance is important to be given to the students. Likewise, Lengkanawati (2017) found that the teachers' guidance is an essential part in promoting the students to be autonomous learners. In terms of teachers' guidance, female students obviously needed to help maintain the autonomy itself. On the other hand, males tend to be influenced by their teachers which is not found among the female respondents. In terms of learning activities, it is in line with the worked of Varol and Yilmaz (2010) that there was no discrepancy between male and female students related to their learning activities.

The second coverage deals with learning strategies use by the autonomous learners. The respondents mostly make planning regarding their learning activities, strategies, as well as learning assignments which is then, they have their learning responsibilities to achieve the learning objectives by employing various learning resources. It is relevant to the study conducted by Chan (2010) finding that the students are able to manage their learning goals in terms of learning preferences, approaches, and as well as their decision in using various learning strategies. Yuliani and Lengkanawati (2017) suggested that collaborative project-based learning was preferred by the students to foster learner autonomy. By gender, Abdel Razeq (2014) found that speaking activity was more popular among female students compared to male ones. In the absence of whether the students prefer speaking or writing activities, they focus more on the level of difficulty. They argued that individuality is at best applied if the activity does not lead to the involvement of deep thinking, while collaboration is at best applied if their needs multiple perspectives and feedback to accomplish such activities. 
The third coverage deals with learning challenges found by the respondents during their learning as autonomous learners. The common challenges were behavioral trait and situational learning process as autonomous learners. This representation is not covered in the previous studies in which laziness, inconsistency toward schedule and mood swing became the contributing factors. Although insufficient proficiency of English was identified in Lengkanawati's (2017) study, the third factor in the present study did not indicate any influence from such proficiency matter. Besides, no gender-based discrepancy was identified.

The last but not least coverage deals with how the autonomous learners encounter those challenges. Findings suggested that there were two main strategies: internal and external strategies. The former was preferred by female respondents realized through rescheduling (Lucy) and maintaining self-commitment (Emma). The latter was preferred by male respondents through looking for other resources from internet, books, and articles (Irvin) and inviting collaborative work with the classmates (Robert). Interestingly, these findings shed light on a better and more comprehensive description related to gender-based problem solving strategies dealing with the challenges mentioned before.

\section{CONCLUSION}

This research is aimed at addressing a questions: "How does learner experience between Indonesian EFL male and female autonomous students differ?" First, there is no obvious gender-based differences related to learning experiences as autonomous learners. Most of the respondents have managed themselves through various learning strategies as autonomous learners. Thus, in gaining the knowledge, besides the guidance of the teachers, they fond of using internet, eBooks, articles, and books provided in library or in digital library. Related to the teacher's assignment, they believe that project, problem-based, mini research, and group presentation will enhance their knowledge related to the subjects and make them involve in collaborative learning. However, even though collaborative learning is beneficial for them, they prefer individual tasks which do not require deep and critical thinking. Indeed, based on their experiences as autonomous learners, they found that behavioral traits and situational learning process as autonomous learners become the main challenges. Therefore, the majority of respondents still need teacher's guidance particularly in the beginning and in the end of the lesson to inform them whether they have met the learning objectives. Then, sharing knowledge to other colleagues, reshaping their learning strategies, and committing to the learning objectives are believed to be able to solve the obstacles. Therefore, as recommendation, the students should be aware of their learning management in order to achieve their learning goals. Whereas, the teachers should guide their students in the process of learning in which to achieve the teaching and learning objectives.

Considering some limitations of the present study, further researches are worth trying to employ observation to gain holistic evidences regarding the actual learning circumstances of the autonomous learners. Besides, it might be beneficial to shed 
light on current literature if the interplay between learner autonomy and self-efficacy is also investigated.

\section{Acknowledgement}

This article is fully funded by Indonesia Endowment Fund for Education (LPDP) Scholarship.

\section{REFERENCES}

Abdel Razeq, A. A. (2014). University EFL Learners' Perceptions of Their Autonomous Learning Responsibilities and Abilities. RELC Journal, 45(3), 321-336. http://doi.org/10.1177/0033688214547035.

Balcikanli, C. (2008). Fostering Learner Autonomy in EFL Classrooms. Kastamonu Education Journal, 16(1), 277-284.

Benson, P. (1997) The multiple meanings of autonomy: responsibility, ability and right, in: L. Dickinson (Ed.) Autonomy 2000: the development of learning independence in language learning (Bangkok, King Mongkut's Institute of Technology Thonburi).

Benson, P. (2001). Teaching and researching autonomy in language learning. Harlow: Longman.

Benson, P. (2013). Teaching and researching: Autonomy in language learning. 2nd edition. London: Routledge.

Benson, P. (2016). Language learner autonomy: exploring teachers' perspectives on theory and practices. In: R. Barnard, \& J. Li (Eds.), Language learner autonomy: Teachers' beliefs and practices in Asian contexts (pp. 114-133). Phnom Penh: IDP Education.

Chan, V. (2010). Teaching in Higher Education Readiness for Learner Autonomy: What do our learners tell us? Readiness for Learner Autonomy: what do our learners tell us ? Teaching in Higher Education, 6(December 2012), 37-41. http://doi.org/10.1080/1356251012007804.

Creswell, John W. (2012). Educational Research: Planning, Conducting, and Evaluating Qualitative and Quantitative Research. Boston: Pearson.

Dickinson, L. (1987). Self-instruction in language learning. Cambridge, England: Cambridge University Press.

Egel, I. (2009). Learner autonomy in the language classroom: from teacher dependency to learner independency. Procedia - Social and Behavioral Sciences 1: 2023-26.

Hamied, F. A. (2017). Research Method: A Guide for First-Time Researchers $\left(^{\text {nd }}\right.$ edition). Bandung: UPI PRESS.

Holec, H. (1981). Autonomy and Foreign Language Learning. Oxford: Pergamon.

Kumaravadivelu, B. (2003). Beyond Methods: Macrostrategies for Language Teaching. London: Yale University Press.

Lengkanawati, N. S. (2017). Learner autonomy in the indonesian efl settings. Indonesian Journal of Applied Linguistics, 6(2), 222-231. 
Lewis, M. and Reinders, H. (2008). Using students-centered methods with teachercentered students. Ontario: Pippin Publishing.

Little, D. (1996). The politics of learner autonomy. Learning Learning, 2(4):7-10.

Macaro, E. (2008). The shifting dimensions of language learner autonomy. In Learner and teacher autonomy: concepts, realities, and responses (pp. 4762). https://doi.org/http://dx.doi.org/10.1075/aals.1.07mac.

Miles, Mathew B. And Huberman, A. Michael. (1994). Qualitative Data Analysis. USA: Sage Publications.

Pennycook, A. (1997) Cultural alternatives and autonomy, in: P. Benson \& P. Voller (Eds) Autonomy and Independence in Language Learning (Harlow, Longman).

Ranosa-Madrunio, M., Tarrayo, V.N., Tupas, R., \& Valdez, P.N. (2016). Learner autonomy: English language teachers' beliefs and practices in the Philippines. In: R. Barnard, \& J. Li (Eds.), Language learner autonomy: Teachers' beliefs and practices in Asian contexts (pp. 114-133). Phnom Penh: IDP Education.

Sugiyono. (2013). Metode penelitian pendidikan: Pendekatan kuantitatif, kualitatif, dan $R \& D$. Bandung: Alfabeta.

Varol, B., \& Yilmaz, S. (2010). Similarities and differences between female and male learners: inside and outside class autonomous language learning activities. Procedia - Social and Behavioral Sciences, 3, 273-274.

Yuliani, Y., \& Lengkanawati, N. S. (2017). Project-based Learning in Promoting Learner Autonomy. Indonesian Journal of Applied Linguistics, 7(2), 285-293. 